\title{
The Tragedy of Holocaust and Possibilities for Reconciliation in the Society of Lithuania
}

\author{
Robertas Pukenis \\ Vytautas Magnus University, Kaunas, Lithuania
}

\begin{abstract}
Holocaust is an eternal topic not only of Jews but of all people of good will. In Lithuania, over 200,000 Jews have been murdered. First, the paper analyses the concept of Holocaust and it proves to be the greatest form of genocide. The development of war and massacre is overviewed. Having been settled since the 13th century, Jews happily lived here, in Lithuania they had "second Jerusalem". They were in good contacts with neighbours but have been sent to death by Nazi occupants. It is a pity that Germans used to find assistants among Lithuanians. Much historical information is presented. Problematic topic penetrates: a rebellion against Nazis on June 23, 1941 and the pogroms (about 50 Jews have been killed in the garage of "Lietūkis" in Kaunas). The Congress of the USA has been investigating that Provisional Government did not manage the situation at that time, the authorities were in the hands of Gestapo. The author tried to perceive the circumstances of that time in an objective and sincere way. Those who raised the hand or took part in execution in an indirect way cannot be approved. With great dignity, the exiles to Siberia are remembered. About 6,000 Jews were among the exiled ones. Much attention is given to analyze how peace process between Jews and Lithuanians takes place. The most important thing is that psychological disagreement would not appear. Jews were, are, and will be the best people of Lithuania.
\end{abstract}

Keywords: Jewish people, Holocaust, anti-Semitism, Nazism, Israel, reconciliation

Holocaust is a constantly discussed topic in Europe. It discloses the tragedy of Jewish nation - the death of six million Jews. It forces us to look back and to see the reasons of that.

The object of the study is Holocaust: its cruelty, killing of civilian people of Jewish origin and the forms of nowadays anti-Semitism; the aim - the discloser of the reasons inspiring all this, is to try to understand why the world was so deaf to the echo of people being murdered. The method is historical but it is not essential to analyse the facts which have been described by the historians. Truly, as rather often not well known sources will be used, thus in quoting, the author will provide longer quotations with the wish that the readers could have an objective opinion (the author leaves the right to the Editorial Board to make it shorter). More attention will be given to the historical context where Holocaust had been executed. The problems will come up in the attempt to reconcile. Is it possible to eliminate the antithesis appearing between the Jews and the part of the society where they live today? The practice of segregation of Jews into ghettos dates back to the 1st century when the Romans, after having suppressed the Jewish rebellion, started to practice the segregation of Jews and to confine them to ghettos. The word "ghetto" was first used in the Venetian dialect in the 12th century. Gheto

Corresponding author: Robertas Pukenis, doctor of law, docent, Department of Public Administration, Faculty of Political Science, Vytautas Magnus University, Kaunas, Lithuania; research fields: international law and post-Soviet space, diplomacy and Roman law. 
meant a place where scrap metal was stored. The original meaning of the "ghetto" designated a site of ironworks, a place where forcefully segregated Jews resided ${ }^{1}$. The focus of the current study has emerged as an attempt to invoke insights on possibilities of reconciliation of opposition that occurs between Jews and societies in which they reside. The discussion on the religious dialogue reflects on the role of the Catholic Church in promoting reconciliation. The subsequent discussion, after having provided the historical context of the Holocaust, analyses processes of reconciliation in a post-Holocaust society with reference to the case of Lithuania.

\section{The Concept of Holocaust}

The destroy of one nation, tribe, or ethnic group is genocide which has no limitation. It is the most horrible crime which could be executed during war and peace time. On December 9, 1948, The General Assembly of the UN (United Nations) approved the Convention about Genocide by determining "the full responsibility not only for state institutions but also private persons for executing genocide"2. The conception of Holocaust covers a systematic physical destroy of Jews. It has been executed by Nazi and their collaborators ${ }^{3}$. Holocaust is a loss of six million Jews. It is one of the most dramatic and painful histories which also means European tragedy, the crisis of Christianity. Nazi has established around 149 camps and 814 semi-imprisonment camps ${ }^{4}$. Distribution and transportation points, ghettos are also included. Some concentration camps differed in better conditions and have been supposed for work. Germans needed labour force. The other ones have been simply supposed for murdering of people. In all camps, at first work has been given to stronger people, while weak and ill ones have been eliminated every day. Most of concentration camps have been located in Germany and Poland. Imprisonment camps, including bigger and smaller, have been secretly settled in 17 states: Norway, Italy, Belgium, the Netherlands, Croatia, Lithuania, Latvia, Estonia, France, Ukraine, Byelorussia, Austria, Czech Republic, the Island of Alderney, and Lager Sylt islands. What a wide system of murder and torture ${ }^{5}$ It took place in three stages. As the historian Linas Venslauskas notices:

Jews cannot change the place of living... not accidentally, in the beginning of 1942, the control of Jewish living mobility was made rather strict — as on January 20, 1942, Wannsee meeting took place where "the final decision" has been taken ... the control of Jewish migration is made stronger in preparing for the third stage - for the catching and deportation to the East... ${ }^{6}$.

Having occupied the other country, Hitler suddenly used to join his Gestapo and administration for the management of that state in order to bring more food products to the army and to joint as much as possible youth to the front. Hitler's tactics was simple: to eliminate political opponents for not to have resistance to the

\footnotetext{
${ }^{1}$ For the meaning of the word "ghetto", see Focus. (2014). Qual è l'origine della parola ghetto (What is the origin of the word ghetto)? Retrieved from http://www.focus.it/cultura/storia/qual-e-l-origine-della-parola-ghetto (accessed 2015, October 12).

${ }_{2}$ Moresca, A. (1991). Dizionario giuridico diplomatico (Diplomatic juridical dictionary) (p. 227). Milano: Giuffrè Editore.

3 Yad Vashem. (2016). The Holocaust: Definition and preliminary discussion. "The Holocaust is part of a broader aggregate of acts of oppression and murder of various ethnic and political groups in Europe by the Nazis. Nevertheless, it has special significance due to the exceptional attitude which its perpetrators - the Nazis — regarded their Jewish victims..." Retrieved from http://www.yadvashem.org/yv/en/holocaust/resource_center/the_holocaust.asp.

${ }^{4}$ Martin Gilbert provides the location of concentration camps in the book Atlas of the Holocaust-May, 1993.

5 The author describes only the panoramic part where death camps had been located. It is impossible to describe exactly how many people had been murdered in each, when the camps started functioning, and when they had been stopped.

${ }^{6}$ Venclauskas, L. (2003). The riddles of stereotypes. Anti-Semitism in Lithuanian and French Press in 1941-1942. Lithuanian Jews (p. 128). Kaunas: Vytauto Didžiojo Universitetas.
} 
new regime; to "clean" the country from Jews and to do this by the hands of those who betrayed". Jews and political opponents have mostly been taken to death camps or destroyed in special places prepared in the country $^{8}$. During the war, concentration camps have been functioning fully. Thousands of war prisoners, Gypsies, leaders of resistance of every nation have been taken there and most often they could not survive bad conditions. When the end of the war was approaching, Hitler even intensified the orders to murder and to hide evidences, e.g., the front is coming up to the city, then Nazi rushed to shoot and to burn the evidence, the live witnesses. There were cases when war prisoners had to be taken to the other camp. It was a great worry for them that the prisoners could have run away (Those who were stepping behind or could not walk had been eliminated $)^{9}$. Then, the free world was despicably deaf, at least it was helpless. This is based on the witness of a German SS officer K. Gerstein, even progressive and good people could not understand what happens in the heart of Christian Europe ${ }^{10}$. A terrible elimination of people took place ${ }^{11}$. It was huge and in all Europe ${ }^{12}$. The same officer was surprised that the allies have not done anything to stop. None of liberation operations from concentration camps prepared by the allies have not been obvious, e.g. to bomb the tracks of railway leading to

\footnotetext{
${ }^{7}$ Gilbert, M. (1993). Atlas of the Holocaust. Hardcover (p. 42). William Morrow Company. "On October 18, 1938, by the order of Hitler 15,000 Germans originating from Poland were announced as the ones without a citizenship and sent away-taken by the border of Poland by train... Soon after 'the Crystal Night' 20,000 of Jews have been arrested an imprisoned...".

${ }^{8}$ Gilbert, M. (1987). The Holocaust: The Jewish tragedy. Retrieved from http://thehealingproject.net.au/wp-content/uploads/ 2010/04/Martin-GILBERT-The-Holocaust-The-Jewish-Tragedy.pdf. "By August 1942, the genocidal machinery was fully operational. During that month alone, over 400,000 Jews were murdered, mainly by gassing, in German-occupied Europe. By the end of 1942, most of Poland's pre-war Jewish communities had been gassed and burned in the concentration camps at Chelmno, Belzec and Sobibor. In the early months of 1944, the process had reached such a pitch that in the Birkenau camp alone, 12,000 Jews were gassed every 24 hours".

9 One of similar episodes: "In January of 1945, the concentration camp of Stutthof is being evacuated as Russian army had been approaching. Germans drove away 823 prisoners to Puck by pushing and beating. Those who could not walk had been shot at once, those stepping behind had been hounded by dogs. The priest Alfonsas Lipniūnas together with other three prisoners had been walking closely for his colleagues could not be shot or hounded by dogs. A heavy pack has been bending the priest to the ground but the priest could not leave it as there were ... the summaries of sermons, things for Holy Masses. The remaining of food has been divided long ago, even the colleagues scolded him as they had to give bread to him now... The remaining prisoners have not been eliminated - in March, in Puck Russians have been already" (The witness of an engineer Pilypas Narutis about the life in Stutthof concentration camp. 1980. These data are used in the Canonisation Case of the priest A. Lipniūnas).

${ }_{10}$ DELFI. (2015b). Tamsiasias naciu paslaptis atskleidęs vyras: Aš viska mačiau (The man who has disclosed the dark secrets of Nazi: I saw everything)! Retrieved from http://www.delfi.lt/news/daily/world/tamsiasias-naciu-paslaptis-atskleides-vyras -as-viskamaciau.d?id=67890162\#ixzz3zrcnzknb. "K. Gerstein also encouraged the participants of Dutch underground movement to broadcast his information on the radio to Great Britain... nothing happened. Nobody wanted to believe in his thrilling stories about massive massacre and rejected it as propaganda. All his efforts to inform Church, the allies and foreign society have been empty. His assumption that after making these facts public the elimination of Jews will be stopped was a mistake".

11 DELFI. (2015b). Tamsiasias naciu paslaptis atskleidęs vyras: Aš viska mačiau (The man who has disclosed the dark secrets of Nazi: I saw everything)! Retrieved from http://www.delfi.lt/news/daily/world/tamsiasias-naciu-paslaptis-atskleides-vyras -as-viskamaciau.d?id=67890162\#ixzz3zrcnzknb. K. Gerstein provides the following picture: "Then, one plump SS man with a loud voice suitable for a priest explained that nothing wrong happens to them (in a gas camera). All you have to do is to breathe deeply. It strengthens the lungs. Inhalations are needed for the prevention of respiratory diseases. It is a perfect method of disinfection. For those listening with fear the mentioned SS man used to reply: men will construct roads and build houses, women will do household works and help in a kitchen. When the doors have closed, diesel engine pumping deathly carbon monoxide gas into the camera was out of order. Till the masters have been repairing the diesel engine, Jews had to wait for their death, all packed like herrings in a tin. Having checked the situation through the glass peephole, SS officer Wilhelm Pfannenstiel announced that Jews are crying like "they do in a synagogue"'.

12 DELFI. (2015b). Tamsiasias naciu paslaptis atskleidęs vyras: Aš viska mačiau (The man who has disclosed the dark secrets of Nazi: I saw everything)! Retrieved from http://www.delfi.lt/news/daily/world/tamsiasias-naciu-paslaptis-atskleides-vyras -as-viskamaciau.d?id=67890162\#ixzz3zrcnzknb. "In 28 minutes only some people were alive. At last, after 32 minutes all were dead. They looked like basalt columns, still standing as there was no place for their bodies to fall. This happened on August 17, 1942... We have three institutions: 1 . Belzec by the suburb road and the railway 'Lublin - Lemberg', by demarcation line with Russia. The maximum capacity is 15,000 people per day; 2 . Treblinka, $120 \mathrm{~km}$ to North from Warsaw. The maximum capacity $-25,000$ people per day; 3 . Sobibor, also in Poland. No exact information, maximum capacity—20,000 people".
} 
a concentration camp. Torture, horror, starvation, work, and elimination of the corpses of prisoners by the hands of prisoners themselves, sneer has been executed by fierce SS officers.

Abundant memories of the survived prisoners witness it. The concentration camp of Auschwitz has been functioning since 1940 to 1945 . There were 1.3 million of prisoners. One point one million of them died from starvation, illness, in gas cameras, or have been shot. Only 200,000 "of the lucky ones" survived. People of various nationality but most of all Jews suffered and died. Three hundred thousand Hungarian Jews have been murdered in Auschwitz camp. This year, the world commemorated the 70th anniversary of liberation of Auschwitz. Only several witnesses remained who at that time had been children prisoners. Whatever pile of memories you take, everyone presents the most cruel, inhuman picture of suffering. Nazi even used to implement medical experiments with their victims ${ }^{13}$. Historians have to specify the number of citizens, despite of nationality, attitudes, who have passed or have not returned from the factories of death. In each state, the historians should make a bibliography of memorial articles, books of all those who had suffered from Nazism and had been the prisoners. Public actors would take care about historical films on this topic, especially dedicated to youth. Such official information should be provided on Internet ${ }^{14}$.

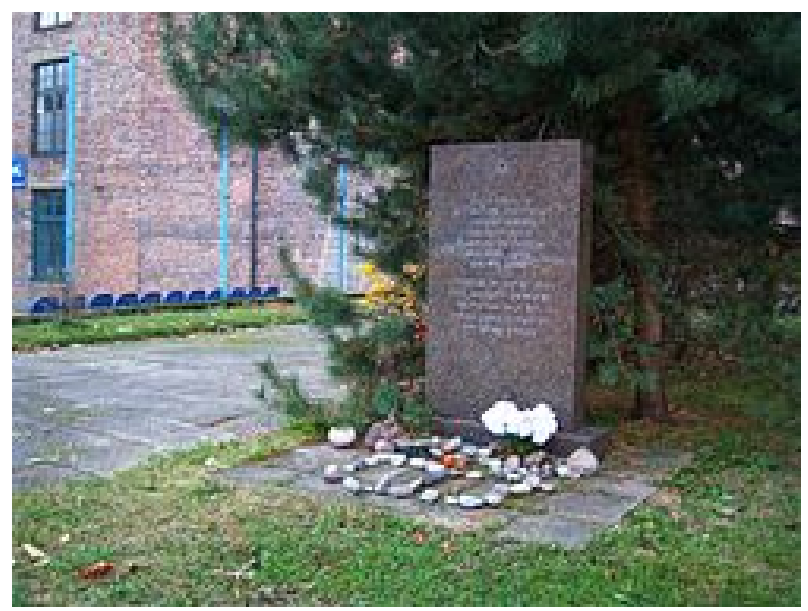

Figure 1. A monument to victims in the place of massacre "Lietūko garažai"15.

\section{Holocaust in Lithuania}

In 1941, when Lithuania had been occupied by Nazi Germany, in several months, a great part of Lithuanian Jewish community was destroyed ${ }^{16}$. Soviet invasion has been coming closer in speedy steps: On

\footnotetext{
13 DELFI. (2015a). Naciu siaubus išgyvenęs vyras: Gyvybę man išgelbejo melas (The man who suffered Nazi horror: A lie helped me to survive). Retrieved from http://www.delfi.lt/news/daily/world/naciu-siaubus-isgyvenes-vyras-gyvybe-man-isgelbejomelas.d?id $=67845168$.

${ }^{14}$ In writing, the author used some sources about the Atlas of the Holocaust where the death camps have been located. Still, he is not sure that the same information fully corresponds to historical truth investigated by scientists. If the author could have a sign "officia", he would not have any doubts.

${ }^{15}$ Lietūkio garažo žudynès (Lietūkis garažai massacre). (n.d.). Retrieved from https://lt.wikipedia.org/wiki/Liet\%C5\%ABkio_ gara\%C5\%BEo_\% C5\%BEudyn\%C4\%97s.

${ }^{16}$ Krupavičius, M. (1986). Lietuviu ir žydu santykiai hitlerio okupacijos metu (The relations of Lithuanians and Jews during the occupation of Hitler. Letters to Lithuanians). Retrieved from http://www.partizanai.org/index.php/bendraminciustraipsniai/251-lietuviu-ir-zydu-santykiai-hitlerio-okupacijos-metu. "Many Jews suffered when already German army has been marching (...) Nazi expressed all their hatred to Jews as soon as civil Nazi authorities has established in Lithuania. At present, they started applying already experienced in their own surroundings and in formerly occupied countries murderous methods of elimination to Jews. They have really been horrible".
} 
June 15, 1940, Lithuanian government approved Stalin's ultimatum after a long meeting. Since July 1 until July 13, Lithuanian Parliament (Seimas) has been dismissed. When Soviets occupied Lithuania, the work of Lithuanian government has soon been stopped, the institutions of security have been eliminated. On June 14, 1941, the first exiles to Siberia started and continued till June 18. "In one year almost 500 Jews have been arrested, in total 2,600 have been repressed. There were 13.5 percent of Jews among the ones exiled in June, it made almost 7 percent of all the inhabitants of the country"17. The situation of all Lithuanians became hopeless. When Germans were attacking the Soviet Union, a rebellion started ${ }^{18}$. Unfortunately, Hitler did not support the idea of Lithuanian independence and placed the Ambassador of Lithuania, the Colonel Kazys Škirpa for home arrest for the latter who could not come to Kaunas and lead the government. After the rebellion of June, 1941, the Temporary Government could not do anything-Its powers are described like this by the participant of the events of that time ${ }^{19}$. There were lots of disputes and even resentment about the activities of Temporary Government in stating that patriots were proud about this struggle during which also some Jews had been murdered. Nevertheless, even the Congress of the USA discussed this question and the activity of Lithuanian Temporary Government was justified. "The Committee of the USA Congress discussed, if the Head of Lithuanian Temporary Government J. Ambrazevičius-Brazaitis is not responsible for Jewish Holocaust in Lithuania. Accusation has later been denied" ${ }^{20}$. At that time, the Government did not control the situation ${ }^{21}$. The same is proved by the famous historian professor Saulius Siužiedèlis: "The activities of Temporary

\footnotetext{
17 Truska, L. (2003). Tikros ir primestos kaltès. Lietuvos žydai. (True and fake blaming. Lithuanian Jews) (p. 105). Kaunas: Vytaytas Magnus University.

18 On June 23, 1941, at 9:28 a.m., Kaunas Radio renewed its broadcasting. On behalf of the Main Headquarters of the Front of Activists (LAF), Leonas Prapuolenis was the first to talk. He read the proclamation on behalf of LAF and announced the regaining of independence of Lithuania. Then, the members of Lithuanian Temporary Government have been presented: the Prime Minister-Colonel Kazys Škirpa, the Minister of National Defence-General Stasys Raštikis, the Minister of Foreign Affairs-Rapolas Skipitis, the Minister of Interrior-Vladas Nasevičius, the Minister of Education—Prof. Juozas Ambrazevičius, the Minister of Agriculture-Prof. Balys Vitkus, the Minister of Finance-Jonas Matulionis, the Minister of Industry-Dr. Engineer Adolfas Damušis, the Minister of Trade-Vytautas Statkus, the Minister of Labour and Social Protection—Dr. Juozas Pajaujis, the Minister of National Economy_Engineer Vytautas Landsbergis-Žemkalnis, the Minister of Transport-Jonas Masiliūnas, State Controller-Jonas Vainauskas. Having come up to the microphone, A. Damušis repeated the announcement in German and Z. Ivinskis did it in French. After the speeches, Lithuanian anthem and a song "Saulele raudona" by Kipras Petrauskas had been performed. That was an arranged sign to struggle. A rebellion required 2,000 of victims. [Brazaitis, J. (2003). J. Ambrazevičiaus-Brazaičio politiniu veiksmu vertinimas Lietuvos Laikinojoje vyriausybeje (Evaluation of political actions of J. Ambrazevicius-Brazaitis in the temporary government of Lithuania). Retrieved from http://mokslai. lt/referatai/ istorija/j-ambrazeviciaus-brazaicio-politiniu-veiksmu-vertinimas-lietuvos-laikinojoje-vyriausybeje. html].

${ }^{19}$ Due to the importance of historical text, the author includes a long extract from the memories of the prelate M. Krupavičius. "The Temporary Government (established on June 25th, 1941) the mouthpiece of the nation under rebellion, well understood that the nation has risen against red slavery not for the sake of Nazi. Thus, by no means, it did not agree to betray the independence which had been committed to the Government. The Nazi had no other way out only to dismiss the Temporary Government. This was done on July 25th, 1941. On that day, Ostaland with Lohse, Lentzen, Renteln, Kramer and the other brown ones in front have been born officially. Nevertheless, until August 5th the Temporary Government continued its activities and during the last meeting it was forced to announce that after the officials of the Reich have taken over the civil authoorities of Lithuania, it has to stop its activities". [Krupavičius, M. (1986). Lietuviu ir žydu santykiai hitlerio okupacijos metu (The relations of Lithuanians and Jews during the occupation of Hitler. Letters to Lithuanians). Retrieved from http://www.partizanai.org/index.php/bendraminciustraipsniai/251-lietuviu-ir-zydu-santykiai-hitlerio-okupacijos-metu].

${ }^{20}$ Lukšas, A. (2009). J. Ambrazevičius-Brazaitis-Vienu vienas (J. Ambrazevičius-Brazaitis-Purely alone). Retrieved from http://www.tv3.lt/m/naujiena/323698/juozas-ambrazevicius-brazaitis-vienu-vienas.

${ }^{21}$ From the memories of the prelate M. Krupavičius. "For nobody could interfere, in the very beginning of occupation, Germans have taken Lithuanian security into their hands, despite of the protest of Temporary Government. Due to this, all arrests and other actions connected with security have been exceptionally the matter of them. People appointed by Germans have been standing in front of the security system". [Krupavičius, M. (1986). Lietuviu ir žydu santykiai hitlerio okupacijos metu (The relations of Lithuanians and Jews during the occupation of Hitler. Letters to Lithuanians). Retrieved from http://www.partizanai.org/index. php/bendraminciu- straipsniai/251-lietuviu-ir-zydu-santykiai-hitlerio-okupacijos-metu].
} 
Government have been restricted. Thus, having none of its tools, it could not influence any excesses in a positive way, e.g. executions taking place in Kaunas and in province, ${ }^{, 22}$. For science objectiveness, let the author include a horrible episode from these tragic events, just to perceive how self-will, in a war situation, can transform into a tragedy also for innocent people.

On June 25, 1941, German army stepped into Kaunas and on the same day the Head of SS A Operational Group Franz Walter Stahlecker came. He encouraged Lithuanian rebels to start pogroms. Inspired by him, Algirdas Klimaitis was the initiator of Vilijampole pogrom during which about 800 Jews from Kaunas have been murdered by Lithuanians. The other massacre took place on June 27, 1941 in a small garage of "Lietūkis" by Žalgiris Street and Vytautas Avenue, in front of Kaunas cemetery. The Headquarters of German 16th Army was approximately 200 metres behind. The versions of tragic massacre are still being investigated. Some say that there were cars by the help of which Soviets wanted to take away the technical equipment and prisoners. Others say that the activists who were against Communism found the representatives of Jews collaborating with the Soviet officers. Despite of the first spark of hatred, the motives of massacre cannot be justified. It is rather sad that about 60 people of Catholic nations had been standing aside and watching... (and later, as heroes, 90 of people testified the investigators and the police). Laimonas Noreika and Vytautas Petkevičius witnessed about the massacre. At that time, they were 11 years old. They had to protect elder people, ask for the help. That damned indifference was in the presence of evil. According to the witnesses, the observers of massacre were mainly the members of German 562nd "bread makers' group". They have not taken any violence but used mockery. About 50 Jews have been killed: among them, the former Director of Industry and Trade Department by the Ministry of Finance of Lithuania-Jurgis Štromas [the son of whom Aleksandras Štromas (1931-1999) survived and became a famous lawyer and an expert of political science in Lithuania], a worker from soap factory Jizchakas Grinas-Simcha Zisl Mankevic, a musician-Šlomas Goldšteinas, a water supplier-I. Kurliančikas, traders-B. Komašas and C. Cukermanas, pupils-Pessachas and Goldbergas, Mošè Štromas (Figure 1: Today, at this place, there is a monument constructed by Kaunas City Municipality and which reminds innocent people of Lithuania-Jews. Historians just have to clarify the surnames and to carve all of them on the memorial plaque by the monument). It is thought that the victims of massacre in the garage of "Lietūkis" had been buried in free space of the Jewish cemetery in Žaliakalnis. Most of the killers had just left Lithuanian prisons... Some say that the guiltiest one was SS officer Joachim Hamann. Others think that it was the Gestapo officer Algirdas Antanas Pavalkis. Arvydas Anušauskas states that it could also be Juozas Surmas, who later spoke that the massacres had been organised together with the driver Franz Walter Stahlecker, Lithuanian German Richard Schweizer. Juozas Surmas and Richard Schweizer both come from Kybartai. Juozas Surmas had organised a group of prisoners, liberated from Kaunas prison.

Lithuanian Temporary Government has analysed the question of the massacre on the same day. The Minister of National Economy-Vytautas Landsbergis-Žemkalnis has announced in the meeting about especially cruel massacre of Jewish in the garage of "Lietūkis". It was decided: The Cabinet agreed that the above mentioned actions are done by people who have nothing in common neither with the Headquarters of the Liberation Activists, nor the Temporary Government. The doctor Balys Matulionis and the priest Simonas Morkūnas have heard from some acquaintances about this crime. They told about it to the Archbishop Juozapas

\footnotetext{
${ }^{22}$ Truska, L. (2003). Tikros ir primestos kaltès. Lietuvos žydai. (True and fake blaming. Lithuanian Jews) (p. 99). Kaunas: Vytaytas Magnus University.
} 
Jonas Skvireckas and asked him to intermediate in negotiating with Germans. The investigators of International Commission on the Crimes of Nazi and Soviet Occupational Regime in Lithuania-Saulius Sužiedèlis and Christoph Dieckmann assure that there are no documents proving that the massacre had been the act of vengeance against security officers. The massacre had been photographed by the Germans Karl Roder and the photographer of Photo Department of the 16th Army Headquarters of German Air Forces-Wilhelm Gunsilius $^{23}$. From the point of view of the Temporary Government, Jews were equal citizens of Lithuania. They have preserved a traditional Lithuanian position toward Jews ${ }^{24}$. Attention should be drawn to the lines of memories of a famous Lithuanian public actor, the Minister of Agriculture, the prelate M. Krupavičius-The situation was really tragic and the Temporary Government could not change $\mathrm{it}^{25}$. Jewish pogroms and

${ }^{23}$ See: In analysing these few sources, it is clear that the whole image of execution could hardly be revived. Bargmanas, C. (2009). Nauja apie žudynes "Lietūkio" garaže (New information about the murder at "Lietūkis" garage). Retrieved from $\mathrm{http}: / /$ www.genocid.lt/centras/lt/899/a/.

A seminar took place at Kaunas Vytautas Magnus University where the events connected with the Jewish massacre in the garage of "Lietūkis" in June of 1941 had been discussed..

DELFI. (2007). "Lietūkio" garažas-Klastočiu pinklèse ("Lietūkis" garage in the trap of forgeries)? Retrieved from http://www.delfi.lt/news/daily/lithuania/lietukio-garazas-klastociu-pinklese.d?id=12723652.

DELFI. (2012). Kaune paminetos žydu žudyniu "Lietūkio" garažu kieme metinès (Commemoration of Jewish massacre in the garage of "Lietūkis"). Retrieved from http://www.delfi.lt/news/daily/lithuania/kaune-paminetos-zydu-zudyniu-lietukio-garazukieme-metines.d?id $=59040435$.

Dieckmann C., \& Sužiedèlis, S. (2015). Pirmosios žydu žudynès (The first massacre of Jewish). Retrieved from http://www. šaltiniai.info/files/istorija/II00/Pirmosios_žydu_žudynès.II0901.pdf.

Mustafinaitè, L. (n.d.). Buvęs partizanu rèmejas J. Abraitis: Tu jaunuoliu gyvenimas buvo siaubingas (Former guerrilla supporter J. Abraitis: The young life was terrific). Retrieved from http://www.delfi.lt/news/daily/lithuania/ buves-partizanu-remejas-j- abraitis-tu-jaunuoliu-gyvenimas-buvo-siaubingas.d?id=67396210.

${ }^{24}$ The Memories of M. Krupavičius. "All sparse bodies of the Temporary Government strongly supported the position in respect to Jews. Kaunas Superintendent the Colonel Bobelis taking his own risk and responsibility, without asking German, went to the IXth Fort on July 18 and liberated all Jewish women and their children, also the men who served Lithuanian army. Besides, he saved also the lawyer Cimkauskas, who at present is in Germany, the trader Misurskis, the engineer Benjaminovičius and others. As much as possible he tried to make the situation of Jews smoother and used to give the notes of protection. Many Jews of Kaunas have received such notes of protection. The members and officials of Jewish Committee should be mentioned here. There were about 50 of them. In some days, the Colonel Bobelis has been dismissed from the duties of the Superintendent. It has to be known that the Colonel Bobelis, as other Lithuanian Superintendents, used to be the Superintendent of the Temporary Government, appointed to the position he fulfilled in the Republic of Independent Lithuania. Thus, not for the duties of the police. He was not a German officer, though Germans required a lot from him, e.g. they required from him and the Mayor of Kaunas Palčiauskas to pen a ghetto for Jews in Vilijampolè. Bobelis and Palčiauskas refused to sign this order. This is not the only example of Kaunas Superintendent with Jews. In all counties, senior Lithuanian officials kept this line". [Krupavičius, M. (1986). Lietuviu ir žydu santykiai hitlerio okupacijos metu (The relations of Lithuanians and Jews during the occupation of Hitler. Letters to Lithuanians). Retrieved from http://www.partizanai.org/index.php/bendraminciu-straipsniai/251-lietuviu-ir-zydu-santykiai -hitlerio-okupacijos-metu].

${ }^{25}$ The Memories of M. Krupavičius. "In the very beginning of Nazi occupation, the Prime Minister of the Temporary Government Prof. J. Ambrazevičius invited the broad meeting on Jewish matters. Almost all ministers took part in it, also the former President Kazys Grinius, the Bishop Vincentas Brizgys and a great number of different political and public actors. The meeting did not last long as all those gathered had the same opinion about the Jewish questions. The behaviour of Nazi had been condemned there and it was decided to help Jews as Lithuanian citizens by all necessary means. If some of them are guilty for Lithuania or Lithuanian nation, to give them to the regained Lithuanian courts and decide on their cases. Unfortunately, already at that time, the participants of the meeting were sure that Jews can be helped a little as in the very beginning of Nazi occupation it was declared that Jews and Poles are taken from the competence of Lithuanian institutions. German Military Superintendents and the established SD institutions took over that competence. SD acting for Lithuanians was not unusual. It was an institution equal to Bolshevik NKVD in its competence and methods of acting. SD institutions did everything on its own; it has not discussed its plans neither with the Lithuanian Government, nor the German Military Superintendents. The new lords openly declared that they are not satisfied when somebody else, except them, is interested in Jewish matters, moreover, when somebody has intentions to plead them or help them". [Krupavičius, M. (1986). Lietuviu ir žydu santykiai hitlerio okupacijos metu (The relations of Lithuanians and Jews during the occupation of Hitler. Letters to Lithuanians). Retrieved from http://www.partizanai.org/index.php/bendraminciu-straipsniai/251-lietuviu-ir-zydu-santykiai-hitlerio-okupacijos -metu]. 
massacres started on the first days of German-Soviet Union War. In Lithuania, hundreds of Jewish inhabitants died due to the implemented Jewish elimination policy in comparison to other European countries as Germans attacking was rapid and Jews did not manage to leave. Part of Lithuanian Jews has been taken to the ghettos established in cities as labour force. In Lithuania, the principle of three stages is applied for the question of Jewish mobility and freedom. Most of the ghettos have been liquidated by Nazi after several months. The remaining ones in Vilnius, Kaunas, and Šiauliai had functioned for 2-3 years. Vilnius Ghetto was eliminated on September 23, 1943. The majority of ghetto inhabitants have been shot in Paneriai, the others have been sent to concentration camps. Having analysed this topic, the historian Dr. A. Bubnys states that almost 2,000 Lithuanian women and children suffered in Auschwitz ${ }^{26}$. Panevėžys Ghetto was eliminated on August 15, 1941. Over 13,500 Jews have been shot. There are over 200 places of massive massacre in the country and the same number of old Jewish cemetery. According to the investigation data of International Historical Justice Commission, 200,000 Jews have been murdered in Lithuania during the war, that is 92-94 percent of the former Jewish community residing in Lithuania. Statistical data quoted by the historian V. J. Čiplyte are also checked:

Before tragic events of 1941, there were 155,124 Jews, that is 7.6 percent of all inhabitants in Lithuania. Together with approximately 85,000 Jews of Vilnius and its surroundings, with 15,000 of Jewish refugees from Poland, the number of Lithuanian Jews reached almost one fourth of a million, that is 10 percent of all Lithuanian inhabitants ${ }^{27}$.

It has to be cleared up that 15,000 Jews are from the total number of those who on June 23, 1941 left for Russia. About 13,000 Jews have been taken to Estonia by Germans. In 1940, 7,000 Jews were deported to Russia and 6,000 Jews managed to emigrate abroad in 1939-1940. Some sources state that there could be from 24,000 to 28,000 Jews who left Lithuania and survived. Forty-five educated Lithuanians have been taken to Stutthof concentration camp ${ }^{28}$. Lithuanian nation resisted against Nazi Germany occupation and its entire ideology. In Lithuania, Nazi did not make any military group neither for the front, nor the SS institutions ${ }^{29}$.

In implementing Holocaust during the years of occupation, executioners have brutally damaged Lithuanian Jewish community which is historic, unique in its language and culture. It helped the state of Lithuania to develop economically. Jewish tragedy is the most painful because a Lithuanian neighbour raised

\footnotetext{
${ }^{26}$ Bubnys, A. (2015). Aušvice kentè beveik du tūkstančiai Lietuvos moteru ir vaiku (Aušvice plagued almost two thousand Lithuanian women and children). Retrieved from http://www.delfi.lt/news/daily/lithuania/a-bubnys-ausvice-kente-beveik-dutukstanciai-lietuvos-moteru-ir-vaiku.d?id=67013474.

27 Čiplytè, J. V. (2001). Amžna knygos tauta. Lietuvos žydu gyvenimo puslapiai (The eternal nation of the book. The pages of the life of Lithuanian Jews) (p. 55). Vilnius: Homo liber.

${ }_{28}$ Among them was the professor priest Alfonsas Lipniūnas. His Canonisation Case is being analysed and can be announced the Saint. The priest Stasys Yla managed to survive, when he left the camp, he wrote memories, worked in cultural field in the town of Putman in the USA.

29 At present in Lithuania, there is the only witness of Stutthof concentration camp-Vladislovas Telksnys, born on January 6 , 1915 , in Runioniai village, Alanta District. When Soviets occupied Lithuania, V. Telksnys together with a group of underground activists have published anti-Soviet newspaper. He was arrested and imprisoned. Only on June 22, 1941 when the war started, he was liberated. Nevertheless, he continued the fight against the new occupant by printing underground press. Secret Nazi German Police arrested the administrator of "Žaibas" Printing House-V.Telksnys and 15 educated public actors from Kaunas on April 27, 1943. On April 29, 1943, the so called Press Group was closed at Stutthof concentration camp. They have changed surname and having become Vladas Lankaitis with a family used to live in Saločiai for three decades until Soviet Secret Services disclosed it. The President Valdas Adamkus has awarded old Vladislovas Telksnys this fighter for freedom with the Fifth Level Order of Vytis Cross and the City of Kaunas - the First Level Sign of Honour of Santaka. See 15min. (2013). 98-year-old Vladislovas Telksnys, the only living survivor of Stutthof concentration camp: "I went through hell". Retrieved from http://www.15min.1t/en/ article/culture-society/98-year-old-vladislovas-telksnys-the-only-living-survivor-of-stutthof-concentration-camp-i-went-through-h ell-528-333701.
} 
the hand in front of the other neighbour in trouble ${ }^{30}$. Fortunately, there were considerably more who sympathised with Jews, understood their tragedy and some managed to save them.

The most difficult task for the author is to answer-How many were of those who got stained with the blood of Jews?: by escorting columns, shooting, taking their property. It is hard for historians to tell the names and numbers precisely. We owe the dead the same we owe the living ones - the truth. A famous Lithuanian journalist A. Vinokurovas thinks as follows: Over twenty thousand participated in the Jewish extermination machine one way or another: Several thousands were killing; others were escorting, taking to the pits, informing, robbing, appropriating their assets. Police battalions, volunteer soldiers, and officers took part in it ${ }^{31}$. Secret Services of Israel possesses a list, which has been made public on Internet by Lithuanian Jewish Association in Israel in 2009. Four thousand two hundred and thirty-three surnames of "Jew-shooters" are on the list. Among them, there are even the Leaders of Lithuanian Partisan Resistance-Adolfas Ramanauskas, Jonas Žemaitis, Juozas Lukša, etc. The most important result of publicly announced investigation was that accusation for the mentioned three persons has no grounds ${ }^{32}$. The experts of the Genocide and Resistance Research Centre of Lithuania who have been working for three years determined that historical material proving the participation of 2,055 persons in Holocaust exists ${ }^{33}$.

Thus, it would be rather hard, even being very objective, to determine an exact number of those who had participated in Holocaust crime in one way or another. Having gone deeper into all this and taking into consideration the talks of people, which have no political shadow, the list of Israel Litvaks, should be shortened. "Our own", the book by Ruta Vanagaite that has just appeared, gives facts and witnesses about the Jew-shooters, tells who they were and why a heavier moral and legal responsibility falls upon them, as there was a possibility to decline. Yes, the Nazi wanted to involve in this dirty job as many Lithuanians as possible, but the Jew-shooters themselves have witnessed that in many cases they could have denied the dirty job (Germans would not have killed them for that). Unfortunately, there were different situations, different Nazi officers and some were made to get involved by force. How can we evaluate those who were forced to collaborate in crime?

By the point of view of Christianity, the one who believes cannot collaborate with the executioners or has to protect the victim but never promise something in murdering the victim. In criminal proceedings, no doubt, if a criminal was forced to implement a crime, it is an advantage. Nobody could say out, measure that

\footnotetext{
${ }^{30}$ The Memories of M. Krupavičius. "When I was in Kalvarija, a civilian young man arrived and told that he was the Head of the mentioned Lublin Military Division. He came to talk with me. His story was horrible (...). When the division was against to implement one or the other task, it was circled by gunned Germans and had to do the task by force. Soldiers used to run away from that division, if they can. The head was ready not to return there and to hide... I praised his attitude and said that it would be great if the whole division could follow the example of the Head. Warsaw division also worked and lived under the same condition. By terror and persecution Gestapo officers forced civilians to carry out unhuman violance and criminal works". [Krupavičius, M. (1986). Lietuviu ir žydu santykiai hitlerio okupacijos metu (The relations of Lithuanians and Jews during the occupation of Hitler. Letters to Lithuanians). Retrieved from http://www.partizanai.org/index. php/bendraminciu-straipsniai/ 251-lietuviu-ir-zydu-santykiai-hitlerio-okupacijos-metu].

31 Vinokuras, A. (2016). Holokaustas iš didžiosios raidès (Holocaust from the capital letter). Retrieved from http://lietuvosdiena. lrytas.lt/aktualijos/holokaustas-is-didziosios-raides.htm.

${ }_{32}$ Glodenis, D. (2016). Kas nuvainikuos nepelnytai pagerbtus, prisidejusius prie Holokausto (Who will dismiss undeservedly honored that contributed to the Holocaust)? Retrieved from http://www.delfi.lt/news/ringas/lit/d-glodenis-kas-nuvainikuosnepelnytai-pagerbtus-prisidejusius-prie-holokausto.d?id=70352118.

33 Glodenis, D. (2016). Kas nuvainikuos nepelnytai pagerbtus, prisidejusius prie Holokausto (Who will dismiss undeservedly honored that contributed to the Holocaust)? Retrieved from http://www.delfi.lt/news/ringas/lit/d-glodenis-kas-nuvainikuosnepelnytai-pagerbtus-prisidejusius-prie-holokausto.d?id=70352118.
} 
psychological pain and humiliation when Jews themselves had been forced to be ghetto policemen, to select the victims for death, in collaborating with Nazi criminals. They secretly thought: "This one is young, perhaps, it will survive, and we have to leave".

Jews relied on Church only or at least, on its certain representatives ${ }^{34}$. During the run of centuries, Lithuanians became tolerant and peaceful to Jews but German occupants, having enslaved Lithuanians, have involved a small part of them into criminal activities. There cannot be any excuse of those bearing blood of innocent people. "Thus, this horrible change had been influenced not by the relations of Lithuanians and Jews but an external factor that is Soviet-Nazi occupation"35. A very important psychological detail is that after 1938 Lithuanian Jews have already known the future, if Lithuania is occupied by A. Hitler and the Soviet Union, let it be a dictatorship state, but J. Stalin had no intentions to eliminate them physically. Thus, the majority of them being afraid of death have turned the political understanding favourable for the Soviets. The facts do not prove that people of other nationalities took part in Soviet repression structure ${ }^{36}$. By the end of 1939, in independent Lithuania, there were 1,120 members of Lithuanian Communist Party (LKP), 670 of them were Lithuanians, 346 were Jews, and others were Poles, Russians, and Germans. Two hundred and eighty-seven Communists, out of them 145 Jews were in prison, thus, Jews made approximately 35 percent of all members of LKP. On January 1, 1941, out of 2,500 members of LKP, 67 percent were Lithuanians, 16.4 percent were Russians and 16.6 percent were Jews ${ }^{37}$. Besides, in accordance to the observation of Lithuanian Security Service, Jewish community was totally different ${ }^{38}$. Nevertheless, by the end of May of 1940, the Chief Rabbi Office "encouraged the Rabbis of the country to support the authorities of Lithuania and to condemn the Jews leaning by the Communist Party"39. Having analysed a number of documents, Saulius Sužiedèlis had not found the fact that Lithuanian Activist Fund (LAF), having carried out the rebellion on June 22, 1941, would have encouraged to murder Jews, though there were some anti-Semitic expressions and accusations toward

\footnotetext{
34 The Memories of M. Krupavičius. "Due to this, Jewish Committee comprising of Kalvarija Rabbi, a teacher and one more influential representative of their nation, the surnames of whom I no longer remember, collected jewellery and brought it to me for keeping on the condition if they come back, it has to be returned to them, if not, it has to be used for Church needs. I have not accepted this by explaining that I was not going to live long in Kalvarija. The jewellery has been handed over to serious farmers. Others, perhaps all, sewed part of their jewellery under the laying of their coats. Having shot Jews, the men of Gestapo found all this and used for their needs. Some days before the mentioned Jewish massacre in Marijampole, the list of 10-15 men has been presented by Germans. They had to come to the indicated institution in Marijampole on the day of shooting. Almost all of the men have been from the reserve non-commissioned officers of Lithuanian Army. They have been foreseen for Jewish shooting. When they realised the reason, they refused to fulfill the duty of executioners. Then, they have been encircled by gunners and threatened: if the order is not fulfilled, they will be shot with Jews. They all have been so shocked by these events that several had nervous psychiatric disabilities. They walked as if mad. They have not found calmness anywhere". [Krupavičius, M. (1986). Lietuviu ir $\check{z} y d u$ santykiai hitlerio okupacijos metu (The relations of Lithuanians and Jews during the occupation of Hitler. Letters to Lithuanians). Retrieved from http://www.partizanai.org/index.php/bendraminciu-straipsniai/251-lietuviu-ir-zydu-santykiaihitlerio-okupacijos-metu].

${ }^{35}$ About Jewish tragedy in Lithuania see the presentation of Emanuelis Zingeris at the conference "The Relations of Lithuanians and Jews. Historical, legal and political aspects". Op. cit.

${ }^{36}$ Truska, L. (2003). Tikros ir primestos kaltès. Lietuvos žydai. (True and fake blaming. Lithuanian Jews) (p. 105). Kaunas: Vytaytas Magnus University. "In spring of 1941, there were approximately 10.6 percent of Jews among NKGB staff in the Soviet Republic of Lithuania, 5.3 percent of Jews were among top level officials, 8.4 percent of Jews among the leading staff of NKV".

37 Truska, L. (2003). Tikros ir primestos kaltès. Lietuvos žydai. (True and fake blaming. Lithuanian Jews) (p. 83). Kaunas: Vytaytas Magnus University. L. Truska is a great, objective scientist and his statements are truly reliable. Besides, it is proved by other famous historians Saulius Sužiedelis and A. Litvak working in Israel Dovas Levinas that accusation of Jews for large scale participation in Soviet structures, not proportionate to the number of inhabitants is not fair.

${ }_{38}$ Truska, L. (2003). Tikros ir primestos kaltès. Lietuvos žydai. (True and fake blaming. Lithuanian Jews) (p. 80). Kaunas: Vytaytas Magnus University.

39 Truska, L. (2003). Tikros ir primestos kaltès. Lietuvos žydai. (True and fake blaming. Lithuanian Jews) (p. 80). Kaunas: Vytaytas Magnus University.
} 
Jews in some of the speeches of its members ${ }^{40}$. No doubt, Germans would like to share the feeling of responsibility with other nations but in any case truth, liberating a human being, has to be found ${ }^{41}$. Truly, Germany paid for the past and the Germans of nowadays generation cannot be made guilty for the past sins and crimes. German nation, just one third of which belonged or sympathised with the Nazi Party, experienced huge violence of revenge from the Red Army. Historian and the Member of the Parliament-Arvydas Anušauskas states that despite of inconsistent violence of Soviet Red Army comparing to the Nazi one, they had been justified on the level of ideology: with the aim to motivate soldiers that it was a revenge for the violence of Nazi. Hoistorians count that about two million German women have been raped by the soldiers of the Red Army, Little Lithuania, which belonged to Germany at that time, also suffered. Massive massacre of civil people of Nemirkiemis (Nemmersdorf) carried out by Soviet soldiers in East Prussia has faced international condemn. The Printing House "Briedis" states: "In some villages all women had been raped despite of their age... Many women died due to injuries resulting from constant raping" in the book "Bloody Lands: Europe between Hitler and Stalin" [Kruvinos žemès: Europa tarp Hitlerio ir Stalino. (2011). Lithuanian: the Printing House "Tyto alba"] $]^{42}$. It was written by the historian Timothy Snyder. In all published front or division newspapers, revenge was stressed. A soldier has to revenge. Finally, the revenge had been transformed into raping $^{43}$. A. Anušauskas, T. Snyder say that massive raping took place in Poland, Germany, Hungary, even Yugoslavia, which became the ally of the Soviets after the revolution. When the Communist of Yugoslavia reported Stalin about the behaviour of Soviet soldiers, he "presented them with a small lecture about soldiers and their 'entertainment"'. Besides, the soldiers of the Red Army themselves have been the products of an extremely cruel Soviet system. There were lots of Gulag prisoners in the front ${ }^{44}$. After the lost World War II, Germans understood what disaster has been brought to Germany and the whole Europe by the Nazism of A. Hitler. Today, Germany is a country of high democratic level, the nation of which is human, educated and not repeating the mistakes of the past. It clearly isolated itself from the past ideology. Unfortunately, the leaders of the Kremlin have not done it up till now.

\footnotetext{
${ }^{40}$ Truska, L. (2003). Tikros ir primestos kaltess. Lietuvos žydai. (True and fake blaming. Lithuanian Jews) (p. 99). Kaunas: Vytaytas Magnus University.

${ }_{41}$ Vasiliauskas, V. (2008). Lietuviu ir žydu santykiai: Popierinis teisingumas (The relations of Lithuanians and Jews: Paper justice). Retrieved from http://www.delfi.lt/news/ringas/lit/vvasiliauskas-lietuviu-ir-zydu-santykiai-popierinis-teisingumas.d?id= 18487509\#ixzz3J7ynnt4X. "I was surprised how a solid German weekly 'Die Zeit' publishes the falsification of KGB colonel: Germans would pleasantly share responsibility on Holocaust with Lithuanians, though anti-Semitism was the essential base of Nazi ideology and the engine of the Third Reich; already in 1939, the top level of Nazi Party approved the decision on 'the final solution of Jewish problem"'.

${ }^{42}$ Samoškaitè, E. (2015). Kodèl Raudonoji armija neatrodo išvaduotoja: Elgèsi tarsi žverrys (Why the Red Army does not look like a liberator: Behaved like wild animals). Retrieved from http://www.delfi.lt/news/daily/lithuania/kodel-raudonoji-armijaneatrodo-isvaduotoja-elgesi-tarsi-zverys.d?id=67800892. "A great number of inhabitants managed to leave but over than 300,000 of civilians (about 130,000 of them being of Lithuanian origin) have been cruelly murdered". "Having stepped into this territory in the beginning, they considered them German lands and carried out the same things which had been done later in East Prussia, East Germany or Berlin: raping, massacre and etc. It is clear from the material of NKVD that all women have been raped, unless she had left Klaipeda region".

${ }^{43}$ Samoškaitè, E. (2015). Kodèl Raudonoji armija neatrodo išvaduotoja: Elgèsi tarsi žverrys (Why the Red Army does not look like a liberator: Behaved like wild animals). Retrieved from http://www.delfi.lt/news/daily/lithuania/kodel-raudonoji-armijaneatrodo-isvaduotoja-elgesi-tarsi-zverys.d?id=67800892.

${ }^{44}$ Samoškaitè, E. (2015). Kodèl Raudonoji armija neatrodo išvaduotoja: Elgèsi tarsi žvèrys (Why the Red Army does not look like a liberator: Behaved like wild animals). Retrieved from http://www.delfi.lt/news/daily/lithuania/kodel-raudonoji-armijaneatrodo-isvaduotoja-elgesi-tarsi-zverys.d?id=67800892.
} 


\section{Reconsilation Between Lithuanians and Jews in a Lithuanian Society}

The public relation with tragic war events in the post-Holocaust society of Lithuania is under investigation: There are attempts to make clear why it happened so, historians have to clarify the data of the dead and injured. It is counted how many Lithuanians, who tried to save Jews, have the name of the righteousness among the nations today. It is written in the Embassy of Israel that 831 Lithuanian citizens used to save Jews. Litvaks are proud about their Lithuanian origin; the others still feel the pain of tragedy and would prefer a more special attention from the state of Lithuania. The encyclopaedia of Litvaks could be compiled; some street could be named after a name of a more famous Litvak. Their music, art could be more promoted. In analysing a long list of famous Litvaks, it has to be noted that they also belonged to different ideologies, sometimes appearing even on different sides of barricades. It is so harmful to the existence of Israel state itself.

Today, only about 5,000 members of Jewish community reside in Lithuania ${ }^{45}$. Also nowadays, Lithuania has perfect Jewish politicians, public actors, scientists. A new Chairperson of Lithuanian Jewish Community-F. Kukliansky is active and positive. She sometimes criticizes appearing anti-Semitic forms but does not make the colours very deep ${ }^{46}$. Since 1988, great event took place in the scope of Lithuanian-Jewish relations. They change these relations into fraternal unity. This is the way how it is described by the member of Lithuanian Sajūdis Movement Initiative Group, the present EU (European Union) Parliament member, a Jew Emanuelis Zingeris at the conference devoted to discuss historical, legal, and political aspects of Lithuanian-Jewish relations ${ }^{47}$ :

In 1988, there was a declaration of Lithuanian intelligentsia which in essence had been a cornerstone application. It was written by M. Martinaitis and other educated persons. The whole Lithuanian political elites have signed under it. On June 7, 1988, in the museum of M. K. Čiurlionis, in Kaunas (during the opening of the first Jewish exhibition), Nasvytis and other active people of Sajūdis Freedom Movement have read the first declaration. Nobody knows that fact. The first declaration of Sajūdis was announced on June 7, 1988. It served as a cornerstone of regaining of Lithuanian-Jewish relations. In June of 1988, in New York, the Chairman of the World Lithuanian Community A. Bieliauskas together with the Jewish Committee in America, me (Emanuelis Zingeris) and with A. Štromas signed a declaration on the regaining of Lithuanian-Jewish relations. This declaration has not been announced. In 1991, here, just several steps behind, the active people of Lithuanian Jews have raised the Jewish, Israel flag in barricades (in protecting the Parliament of the Republic of Lithuania from Russian Army attacking) (...). On September 23, 1991, in Paneriai, G. Vagnorius excused, in 1993, there was A. Brazauskas visit to Israel. During it he said very strong words... Arranging of cemeteries, which seemed a boring moment but is crucial (...). Here sits Josif Levinson, who has devoted all his life for the arranging of Jewish cemeteries. This happened on the account of Lithuanian Catholic community, the Jews who remained alive and the state of Lithuania... 200 cemeteries in the places of massive massacre had been arranged. At last, it is written that not Soviet citizens but local Jews-from Telšiai, Plungè, who had been murdered by Nazi and local collaborates rest here. (...). V. Landsbergis, the present Chairman of the Parliament, supported (this document has not been announced anywhere) the excuse of A.

\footnotetext{
45 Since 1992 till 2014, Dr. A. Alperavičius was the leader of Lithuanian Jewish Community and on November 16, the Chairperson of Jewish Comunity became Mrs. F. Kukliansky, her deputies are the former mmeber of European Parliament, a well-known public actor Prof. Leonidas Donskis, Mrs. Maša Grodnikienė, and the Chairman of Ukmerge Jewish Comunity Artūras Taicas.

${ }^{46}$ Kukliansky, F. (2015). Žydai Lietuvoje neturi daug kuo skustis (Jews do not have much to complain in Lithuania). Retrieved from http://www.delfi.lt/news/daily/lithuania/f-kukliansky-zydai-lietuvoje-neturi-daug-kuo-skustis.d?id=65373548\#ixzz3JRrVM VLe.

${ }^{47}$ Emanuelis Zingeris (born on July 16, 1957, in Kaunas, Lithuania) is a Lithuanian philologist, museum director, politician, signatory of the Act of the Re-Establishment of the State of Lithuania (1990), currently serving as a member of the Seimas (1990-2000 and since 2004), chairman of its foreign affairs committee (since 2010), vice president of the Parliamentary Assembly of the Council of Europe (since 2009) and president of the Parliamentary Forum of the Community of Democracies (since 2010). A Lithuanian Jew, he has been director of the Vilna Gaon Jewish State Museum, honorary chairman of Lithuania's Jewish community, and is chairman of the International Commission for the Evaluation of the Crimes of the Nazi and Soviet Occupation Regimes in Lithuania. He is a founding signatory of the Prague Declaration on European Conscience and Communism, that proposed the establishment of the European Day of Remembrance for Victims of Stalinism and Nazism.
} 
Brazauskas. This happened in June of 1995. I think that the last moment is September 7, 1998, when the President of Lithuania V. Adamkus established an International Commission on the Evaluation of Crimes of Nazi and Soviet Occupational Regimes in Lithuania (...). A financial support has been received from the Government and it started functioning as a separate organisation. Such are the facts ${ }^{48}$.

In 1994, the Parliament of the Republic of Lithuania announced September 23 the State Memorial Day ${ }^{49}$. September 23 is a sad and important memorial day in the history of Lithuania as in 1943, on that day, the Ghetto of Vilnius was liquidated and part of its inhabitants had been shot in Paneriai (in Vilnius), others had been taken away from Lithuania to concentration camps.

During the period of independence of Lithuania, Jewish communities spread invitations for more people to come to commemorate the victims. In Figure 2, it is written: "The community of Lithuanian Jews (Litvaks) invites to remember International Holocaust Day together on 26 January, 2015".

Having in mind a hard Jewish geopolitical situation, Lithuanian government, supports a diplomatic line of Jerusalem government in a reserved way but also expresses the wish that the nation of Palestinians could create their own state as soon as possible ${ }^{50}$. Radical elements rising against the policy of their government appear in each state. Fortunately, press did not show much attention and it was escaped from irrelevant slander campaign against Israel $^{51}$. Sometimes, due to a random disrespectful case, which comes up from the lack of general culture or stupidity, Lithuanians should not be made guilty at once for anti-Semitism ${ }^{52}$.

It was not easy to solve the question of property return to Jews as the war, nationalisation carried out by Soviet regime had either destroyed everything or scattered. Besides, "There are opposing sides among them, sometimes they see angry intentions in their own activities, though this thinking, if not based on facts, cannot be evaluated in advance as illegal activity", states R. Pilibaitis and adds that "When private auditors determined infringements, the Government leaves the right to stop the payment of compensation". Totally, 128 million Litas is foreseen to be allocated from Compensation Fund, the allocations have already been transferred: in

\footnotetext{
${ }^{48}$ Zingeris, E. (1999). Lietuviu-žydu santykiai. Istoriniai, teisiniai ir politiniai aspektai (The relations of Lithuanians and Jews. Historical, legal and political aspects). Retrieved from http://genocid.lt/GRTD/Konferencijos/lietuvi.htm. E. Zingeris is a special personality of Lithuanian Jews, a political actor of international level, thus, it was worthwhile to provide the quotation of half of the page in the work. Explanations are added in the brackets, the text is shortened just by some sentences.

49 Memorial Day for Genocide Victims of Lithuanian Jews. Go to http://www.komisija.lt/lt/body.php?\&m=1176281410. Information about organised events and conferences is available on this website.

50 DELFI. (2014). Izraelis ivertino Lietuvos pozicija (Israel appreciates the position of Lithuania). Retrieved from http://www.delfi.lt/news/daily/lithuania/izraelis-ivertino-lietuvos-pozicija.d?id=65804616. The Minister of Foreign Affairs of Israel Avigdor Lieberman has positively evaluated Lithuania for its smart position, which it had been keeping in the Council of Security of the UN concerning the conflict in the Near East: "I would like to express my appreciation for your country for a well balanced and very responsible position during the recent two months in the Council of Security concerning our war against terror in the Strip of Gaza".

${ }^{51}$ Klimka, K. (2014). Ar egzistuoja oficiali Lietuvos pozicija dèl karo Gazoje (Is there an official position of Lithuania concerning the war in Gaza)? Retrieved from http://www.delfi.lt/news/ringas/lit/k-klimka-ar-egzistuoja-oficiali-lietuvos-pozicija -del-karo-gazoje.d?id=65474474. "Are there any palliative circumstances due to which we should restrict from conclusion that complete silence about the tragedy of Palestine is reliable evidence. The Republic of Lithuania wants to please strategic partners and this unsound fear freezes the agenda of the politics (...). Does the Republic of Lithuania have an official position concerning these events?".

${ }_{52}$ Povilaitis, N. (2015). Žudyniu vietoje-Gedingas renginys (In the place of massacre-A shameful event). Retrieved from $\mathrm{http}$ //lietuvosdiena.lrytas.lt/aktualijos/zudyniu-vietoje-gedingas-reginys.htm. In the very heart of Kaunas, in Miškas Street, in the yard of S. Darius and S. Girenas Gymnasium, there were waste containers by the Monument for Murdered Jews. They have been standing here for several years and the inhabitants of Kaunas have been already used to them. They have not passed through the eyes of the Lithuanian emigrant living in Israel Daniel Lupshitz. He personally applied the authorities of Kaunas City. Being shameful, the latter have rapidly solved the problem. The same impolite behaviour can be applied to the officials of Vilnius Municipality when a toilet has been opened by the Monument for the Murdered Priest Br. Laurinavičius.
} 
2012 - three million, in 2013-12.5 million ${ }^{53}$. The contribution of Lithuanian Jews into the welfare of our national economy and culture is enormous. It is historical and cannot be denied. Lithuanian Jews, especially Litvaks, are an inseparable part of the state inhabitants. Each citizen, especially a Christian one, has to be sensitive and not tolerate anti-Semitic or anti-Racist manifestations (also small ones). All nations are created by God for a common peaceful life. Inter-religious dialogue helps to disperse suspicion, religious fanatics and historical studies help to understand the facts covered by propaganda on purpose. Thus, every patriot of its country has to perceive that during the World War II the only safe place for Jews in East Europe was the Soviet Union. Though, every Israelite also has to understand that an ordinary Lithuanian, being afraid of Siberia and hiding in a wood, has not been a helper for a German. It is a must to check, observe, and analyse the facts as they are not announced up till now. Historical and iconographic material about cultural, social, and economic life of Lithuanian Jews during the period between the wars has to be collected and accumulated. A unique monument has to be erected for Lithuanian Jews murdered during Holocaust and also the one, great for all who fought for Lithuanian freedom.

Therefore, what contents should prevail in the dialogue between Lithuanians and Jews: Holocaust is to be written with the initial capital letter. The Jews were and will be among people creating Lithuania. Thus, the Holocaust is a common tragedy casted by occupation of the Nazis. It is a cruel tragedy: Parents were being killed when their kids were jumping around ${ }^{54}$. It has already been examined and proved on the basis of the sources of true historians, that the percentage of Jews, who participated in crimes of Communism and its creation, was no bigger than that of the other nations. Therefore, they cannot be reproached with the crimes of Communism. The Jewish people have to understand as well our pain, occupations, exiles, and massacres and should not be afraid of the formula: Crimes of Communism and Nazism are equal. Therefore, we cannot automatically suspect those, who fought and died for the freedom of Lithuania, of shooting the Jews. Let the historians do the job here. If the fact of the crime is proven, a juridical part comes into effect: The law on the legal status of the participants of the resistance to occupation in 1940-1990, Article 6, Part 1, Item 1 defines that a volunteer soldier status is not acknowledged for the persons who committed war crimes and crimes against humanity, ordered to kill or killed peaceful citizens or participated in executing these crimes. Thus, to generalise, in the words of the journalist it can be said: There are no grounds to state that Lithuanians, all as a nation, were exterminators of Jews ${ }^{55}$. The wounds of the Jewish nation have to be healed by all together and the first to pronounce it were the heads of the State of Lithuania.

\footnotetext{
53 About the allocations of Compensation Fund. Please see http://kauno.diena.lt/naujienos/lietuva/salies-pulsas/zydu-turtograzinimo-nebekontroliuos-505867\#ixzz3FeApwVxH.

54 DELFI. (2016). Žudiko pasakojimas: Tèvus šaudème, o vaikai šokinejo aplinkui (A story of a killer: We were killing the parents while the children were jumping around). Retrieved from http://www.delfi.lt/news/daily/lithuania/zudiko-pasakojimastevus-saudeme-o-vaikai-sokinejo-aplinkui.d?id=70193286.

${ }_{55}$ Vinokuras, A. (2016). Holokaustas iš didžiosios raidès (Holocaust from the capital letter). Retrieved from http://lietuvosdiena. lrytas.lt/aktualijos/holokaustas-is-didziosios-raides.htm.
} 


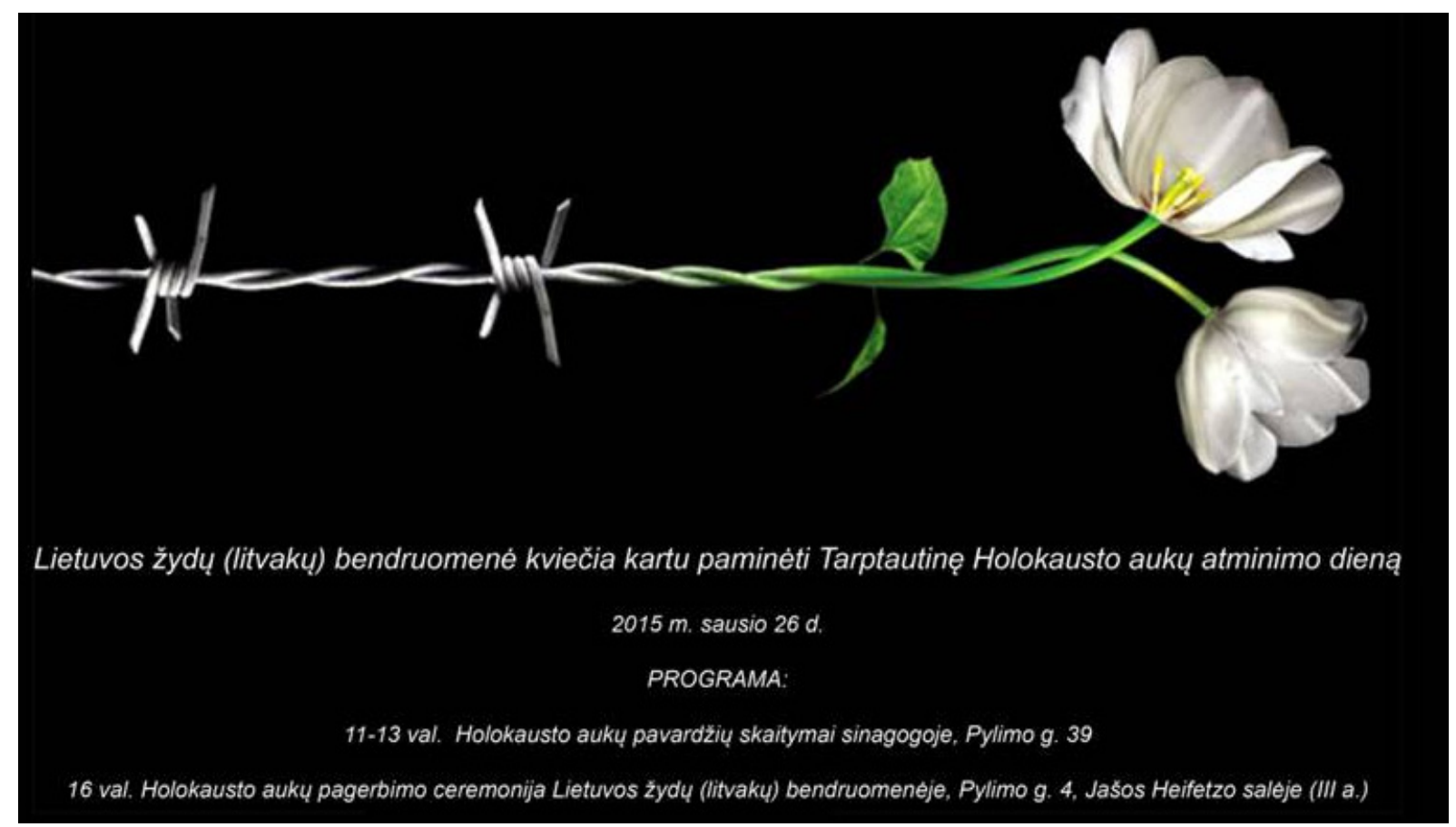

Figure 2. Invitation to the commemoration of the Holocaust victims organised by Lithuanian Jews (Litvaks), programme cover.

\section{Conclusions}

All this geopolitical situation of the beginning of the 20th century provided the base that Hitler, having occupied half of Europe, has attacked the Soviet Union. He performed in the way he wanted in the occupied countries. The West was not fully sure that Germany could face the massacre of such scope.

Lithuania has been strictly implementing anti-Nazi policy. It was one of the rare states which already before the World War II judged Nazi for their sabotage activities in Klaipeda region. Lithuania has been implementing anti-Nazi policy strictly.

The Committee of NGO (Non-Governmental Organization) which could react in all possible legal ways toward one-sided, illogical speaches against "Jewish occupants" encouraging anti-Semitism and terroristic moods has to be established. Europeans and Jews should always feel the support of each other and solidarity in fighting for peace, common security, and progress. If the State of Israel collapses, EU security by the southern borders will become worse immensely.

The Government of Israel invites Jews to come back to their historical homeland and they have to strengthen relations with the Jews living abroad that the latter would not lose Jewish identity and would contribute to the development of democracy and progress in each nation, decrease anti-Semitism and protect human rights in the state they live. Earlier anti-Semitism used to evoke from the radicals of the right side and today, it is on the contrary, from the left wing parties.

Holocaust has been the destruction of Jewish nation by Nazi. There is no doubt that Holocaust has been the largest crime against humankind, the strongest and the most vivid form of genocide. From the point of science, Holocaust is larger evil than the deportation of Stalin but the suffering of one person and death, coming from the repressions of dictatorship is evil, obtaining the condemnation from the society. What if this evil has reached millions? This has to be presented at Israel schools as the member of EU Parliament E. Zingeris stated. 
The best representatives of many nations have suffered from Hitler and Stalin. Reliable historical sources prove that it is not right to blame Jews for the participation in Stalin's repression structures. According to the percentage, the number of such people was even less than the one of the other nations. Holocaust has been implemented in Lithuania as well. For about 200,000 Jews have been murdered who had been living here in peace and happiness since the 13th century. Vilnius was even called the third Jerusalem. It is well to notice that Lithuanian Jews themselves connect the essence of tragedy with Nazi occupation where local executioners had been joined. Legal responsibility is applied only to the people who had directly contributed to the crimes of humankind; he (Štromas) applies the validity of moral responsibility to the whole nation ${ }^{56}$. Longer quotations of memories disclose the sorrow of consciousness of people who had been forced to help the occupants to eliminate Jews. Those who did it by their own will cannot wait for any justification, even after their death, and the society has to condemn them legally and morally.

Fortunately, Nazi did not manage to establish any division supporting the fight of them. Many Lithuanians also suffered the supporters of Hitler. The Government of Lithuania excused for the past mistakes and put all the efforts to return Jewish property. At last, there is no space for anti-Semitism to develop in Lithuanian democratic society. Lithuanian government fully understands a complicated geopolitical situation of Jerusalem and the UN supports the position of Israel.

All democratic states of the world commemorate Holocaust victims. In the USA, an annual Day of Holocaust is a national event. The Day of Holocaust is also commemorated in Lithuania. European Jews, among them being a small part of Lithuanian Jews, have to raise their moral and spiritual understanding in taking part in the life of their states without the nightmares of the past. Together with other nations, peaceful, free, and humanistic future of Europe has to be created.

It is not enough to observe political situation, the psychology of nations but prevention has also been taken in time to avoid large scale catastrophe in Near East—nuclear Holocaust. It is believed that the Jews of the world understand international situation and will strongly support their brave Prime Minister Netanyahu protecting the security of Israel. The nation of Israel, the parents and grandparents of which have suffered this terrible masacre, is alert and has the right to observe the manifestations of anti-Semitism in any state in order to eliminate them in time. History is mentioned not for revenge but for understanding it in a proper way and not to repeat it again.

\section{References}

15min. (2013). 98-year-old Vladislovas Telksnys, the only living survivor of Stutthof concentration camp: "I went through hell". Retrieved from http://www.15min.lt/en/article/culture-society/98-year-old-vladislovas-telksnys-the-only-living-survivor-of -stutthof-concentration-camp-i-went-through-hell-528-333701

2000 m. Kauno Vytauto Didžiojo universitete i̇vyko seminaras, kuriame buvo nagrinejjami ivvykiai, susiję su žydų žudynėmis buvusiame "Lietūkio" garaže 1941 m. birželio mèn (In 2000 a seminar took place at Kaunas Vytautas Magnus University where the events connected with the Jewish massacre in the garage of "Lietūkis" in June of 1941 had been discussed). Retrieved from http://Nuomonè-Genocid.lt genocid.lt/centras/lt/899/a/

Bargman, C. (2009). Nauja apie žudynes "Lietūkio" garaže. Kiek garažu buvo (New facts about the massacre in the garage of "Lietūkis". How many garages were there)? Retrieved from http://www.genocid.lt/centras/lt/899/a/

\footnotetext{
${ }^{56}$ Donskis, L. (2005). Tomas Venclova: Etinis universalizmas ir kito atradimas (Tomas Venclova: Ethical universalism and discovery of something else) (pp. 157-202). Tapatybe ir laisvè. Trys intelektualiniai potretai (Identity and Freedom. Three intelectual potraits). Vilnius: Versus Aureus. Retrieved from http://www.šaltiniai.info/files/literatura/LH00/Leonidas_Donskis. Tomas_Venclova.LHR701C.pdf. "To this respect, Venclova has similarities with Karl Jaspers, who has described legal, moral and metaphysical aspects taking into account the question of guilt during after the war period".
} 
Bargmanas, C. (2009). Nauja apie žudynes “Lietūkio” garaže (New information about the murder at "Lietūkis” garage). Retrieved from http://www.genocid.lt/centras/lt/899/a/

Brazaitis, J. (2003). J. Ambrazevičiaus-Brazaičio politiniu veiksmu vertinimas Lietuvos Laikinojoje vyriausybëje (Evaluation of political actions of J. Ambrazevičius-Brazaitis in the temporary government of Lithuania). Retrieved from http://mokslai.lt/ referatai/istorija/j-ambrazeviciaus-brazaicio-politiniu-veiksmu-vertinimas-lietuvos-laikinojoje-vyriausybeje.html

Bubnys, A. (2015). Aušvice kentè beveik du tūkstančiai Lietuvos moteru ir vaiku (Aušvice plagued almost two thousand Lithuanian women and children). Retrieved from http://www.delfi.lt/news/daily/lithuania/a-bubnys-ausvice-kente-beveik-dutukstanciai-lietuvos-moteru-ir-vaiku.d?id $=67013474$

Čiplytė, J. V. (2001). Amžna knygos tauta. Lietuvos žydu gyvenimo puslapiai (The eternal nation of the book. The pages of the life of Lithuanian Jews). Vilnius: Homo liber.

DELFI. (2007). "Lietūkio" garažas—Klastočiu pinklèse ("Lietūkis" garage in the trap of forgeries)? Retrieved from http://www.delfi.lt/news/daily/lithuania/lietukio-garazas-klastociu-pinklese.d?id=12723652

DELFI. (2012). Kaune paminètos žydu žudyniu “Lietūkio" garažu kieme metinès (Commemoration of Jewish massacre in the garage of "Lietūkis"). Retrieved from http://www.delfi.lt/news/daily/lithuania/kaune-paminetos-zydu-zudyniu-lietukiogarazu-kieme-metines.d?id=59040435

DELFI. (2014). Izraelis ivertino Lietuvos pozicija (Israel appreciates the position of Lithuania). Retrieved from http://www.delfi.lt/news/daily/lithuania/izraelis-ivertino-lietuvos-pozicija.d?id=65804616

DELFI. (2015a). Naciu siaubus išgyvenęs vyras: Gyvybę man išgelbejo melas (The man who suffered Nazi horror: A lie helped me to survive). Retrieved from http://www.delfi.lt/news/daily/world/naciu-siaubus-isgyvenes-vyras-gyvybe-man-isgelbejomelas.d?id=67845168

DELFI. (2015b). Tamsiqsias naciu paslaptis atskleidęs vyras: Ǎ̌ viska mačiau (The man who has disclosed the dark secrets of Nazi: I saw everything)! Retrieved from http://www.delfi.lt/news/daily/world/tamsiasias-naciu-paslaptis-atskleides-vyras -as-viskamaciau.d?id=67890162\#ixzz3zrcnzknb

DELFI. (2016). Žudiko pasakojimas: Tèvus šaudeme, o vaikai šokinèjo aplinkui (A story of a killer: We were killing the parents while the children were jumping around). Retrieved from http://www.delfi.lt/news/daily/lithuania/zudiko-pasakojimas-tevussaudeme-o-vaikai-sokinejo-aplinkui.d?id=70193286

Dieckmann, C., \& Sužiedèlis, S. (2015). Pirmosios žydu žudynès (The first massacre of Jewish). Retrieved from http://www. šaltiniai.info/ files/istorija/III00/Pirmosios_žydu_žudynès.II0901.pdf

Donskis, L. (2005). Tomas Venclova: Etinis universalizmas ir kito atradimas (Tomas Venclova: Ethical universalism and discovery of something else) (pp. 157-202). Tapatybė ir laisvè. Trys intelektualiniai potretai (Identity and Freedom. Three intelectual potraits). Vilnius: Versus Aureus. Retrieved from http://www.šaltiniai.info/files/literatura/LH00/Leonidas_ Donskis._Tomas_Venclova.LHR701C.pdf

Focus. (2014). Qual è l'origine della parola ghetto (What is the origin of the word ghetto)? Retrieved from http://www.focus.it/cultura/storia/qual-e-1-origine-della-parola-ghetto

Gilbert, M. (1987). The Holocaust: The Jewish tragedy. Retrieved from http://thehealingproject.net.au/wp-content/uploads/ 2010/04/Martin-GILBERT-The-Holocaust-The-Jewish-Tragedy.pdf

Gilbert, M. (1993). Atlas of the Holocaust. Hardcover. William Morrow Company.

Gilbert, M. (2001). Niekada per amžius. Holokausto istorija (Never again. A history of the Holocaust). Vilnius: R. Paknio Leidykla.

Glodenis, D. (2016). Kas nuvainikuos nepelnytai pagerbtus, prisidejusius prie Holokausto (Who will dismiss undeservedly honored that contributed to the Holocaust)? Retrieved from http://www.delfi.lt/news/ringas/lit/d-glodenis-kas-nuvainikuos -nepelnytai-pagerbtus-prisidejusius-prie-holokausto.d?id=70352118

Klimka, K. (2014). Ar egzistuoja oficiali Lietuvos pozicija dèl karo Gazoje (Is there an official position of Lithuania due to the war in Gaza)? Retrieved from http://www.delfi.lt/news/ringas/lit/k-klimka-ar-egzistuoja-oficiali-lietuvos-pozicija-del-karogazoje.d?id=65474474

Krupavičius, M. (1986). Lietuviu ir žydu santykiai hitlerio okupacijos metu (The relations of Lithuanians and Jews during the occupation of Hitler. Letters to Lithuanians). Retrieved from http://www.partizanai.org/index.php/bendraminciu-straipsniai/ 251-lietuviu-ir-zydu-santykiai-hitlerio-okupacijos-metu

Kukliansky, F. (2015). Žydai Lietuvoje neturi daug kuo skustis (Jews do not have much to complain in Lithuania). Retrieved from http://www.delfi.lt/news/daily/lithuania/f-kukliansky-zydai-lietuvoje-neturi-daug-kuo-skustis.d?id=65373548\#ixzz3JRrVMV Le 
Lietuvos žydu genocido auku atminimo diena (The commemoration of genocide victims of Lithuanian Jews). (n.d.). Retrieved from http://www.komisija.lt/lt/body.php?\&m=1176281410

Lukšas, A. (2009). J. Ambrazevičius-Brazaitis-Vienu vienas (J. Ambrazevičius-Brazaitis-Purely alone). Retrieved from http://www.tv3.1t/m/naujiena/323698/juozas-ambrazevicius-brazaitis-vienu-vienas

Moresca, A. (1991). Dizionario giuridico diplomatico (Diplomatic juridical dictionary). Milano: Giuffrè Editore.

Narutis, P. (1980). Naručio, Pilypo inžinieriaus liudijimas apie gyvenimą Štuthofo koncentracijos stovykloje (The witness of an engineer Pilypas Narutis about the life in Stutthof concentration camp). Rankraštis, naudojamas kunigo A Lipniūno kanonizacijos byloje (This data is used in the Canonisation Case of the priest A. Lipniūnas).

Povilaitis, N. (2015). Žudyniu vietoje-Gedingas renginys (In the place of massacre-A shameful event). Retrieved from http://lietuvosdiena.lrytas.lt/aktualijos/zudyniu-vietoje-gedingas-reginys.htm

Samoškaitè, E. (2015). Kodèl Raudonoji armija neatrodo išvaduotoja: Elgèsi tarsi žvèrys (Why the Red Army does not look like a liberator: Behaved like wild animals). Retrieved from http://www.delfi.lt/news/daily/lithuania/kodel-raudonoji-armijaneatrodo-isvaduotoja-elgesi-tarsi-zverys.d?id=67800892

Truska, L. (2003). Tikros ir primestos kaltès. Lietuvos žydai (True and fake blaming. Lithuanian Jews). Kaunas: Vytaytas Magnus University.

Vasiliauskas, V. (2008). Lietuviu ir žydu santykiai: Popierinis teisingumas (The relations of Lithuanians and Jews: Paper justice). Retrieved from http://www.delfi.lt/news/ringas/lit/vvasiliauskas-lietuviu-ir-zydu-santykiai-popierinis-teisingumas.d?id= 18487509\#ixzz3J7ynnt4X

Venclauskas, L. (2003). The riddles of stereotypes. Anti-Semitism in Lithuanian and French Press in 1941-1942. Lithuanian Jews. Kaunas: Vytauto Didžiojo Universitetas.

Vinokuras, A. (2016). Holokaustas iš didžiosios raidès (Holocaust from the capital letter). Retrieved from http://lietuvosdiena. lrytas.lt/aktualijos/holokaustas-is-didziosios-raides.htm

Vogelsang, P., \& Larsen, B. B. M. (2002). The Nazi ideology. Retrieved from http://www.holocaust-education.dk/baggrund/ nazismensideologi.asp

Yad Vashem. (2016). The Holocaust: Definition and preliminary discussion. Retrieved from http://www.yadvashem. org/yv/en/holocaust/resource_center/the_holocaust.asp

Zingeris, E. (1999). Lietuviu-žydu santykiai. Istoriniai, teisiniai ir politiniai aspektai (The relations of Lithuanians and Jews. Historical, legal and political aspects). Retrieved from http://genocid.lt/GRTD/Konferencijos/lietuvi.htm 